\title{
ON A SECTION OF THE GAULT AND LOWER GREENSAND, AT LOWER FETTLEWORTH, SUSSEX.
}

SIR,-The papers by Mr. Judd on the Speeton Clay, and the Rev. T. Wiltshire on the Red Chalk of Hunstanton, which have recently appeared in the Quart. Journ. of the Geological Society, suggest my sending for publication the accompanying sketch of a section exposed in a cutting of the Petworth Railway, near Lower Fettleworth, Sussex, exhibiting the occurrence of a blood-red bed in association with Gault, and probably on the horizon of the Red-rock of Hunstanton and Speeton.

The section, which is from forty to fifty feet deep, exhibits four well-marked subdivisions.

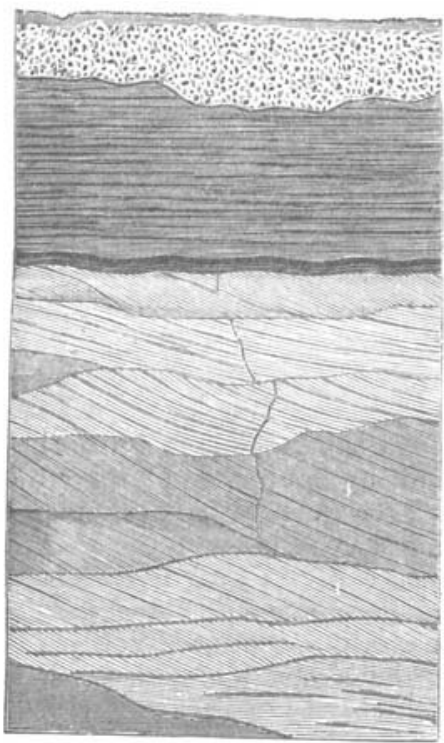
(A) A bed of ferruginous surface gravel, five
or six feet thick.

(B) Ganit about ten feet thick.

(c) A very hard blood-red ferruginous con-

(D) glomerate at the base of the Gault, maintaining a uniform thickness of about four inches, and resting on

(E) The Lower Greensand, thirty feet of which is exposed in the cutting. The colour of the Lower Greensand varies from buff to orange; its upper part, (D), immediately under the band (c) being stained to the depth of a few inches of a bright blood-red.

The peculiar clear red of anhydrous sesquioxide of iron is rare in the British Cretaceous rocks, and notably distinct from the yellow and orange tints pervading the Lower Greensand. The red band c, like the red rock at Hunstanton, abounds in small quartz pebbles, held together by the ferruginous matrix.

Is it possible that it may be the southern extension of the red rock of Hunstanton and Speeton, expanded to six or seven feet thick at Hunstanton, and further north to thirty feet at Speeton? The Gault does not seem to have any certain representative in the north. The position of the Fettleworth red bed at the top of the Lower Greensand agrees with that assigned by Mr. Wiltshire for the Hunstanton red-rock overlying the "Carstone," and is not inconsistent with the horizon suggested by Mr. Judd for the Red Chalk, south of Speeton, resting unconformably on beds supposed to be the equivalent of the Upper Neocomian. 
The intercalation of a thin red band, largely composed of anhydrous sesquioxide of iron, between beds of such different physical character, is difficult of explanation. The line of demarcation is remarkably definite, no gradation existing between the red stratum and the Gault above or the Lower Greensand below.-Gro. Maw.

Benthaxt Haxt, BroseLY, May 28th, 1869.

\section{SINGULAR SUBSIDENCE AT MARTON.}

SIR,-In reply to Mr. J. W. Wilson's description of a singular subsidence at Marton, near Northwich, perhaps I may be allowed to remark that the phenomenon is not so rare as may be imagined. When living in Cheshire I frequently heard of similar subsidences taking place. These occurred in every instance on the Keuper formation, and I attributed them to the dissolving away of a good portion of the rock salt, which frequently attains a thickness of nearly a hundred feet, by the percolation of running water. Considering the vast quantity of solid salt held in solution by the brine springs, this can hardly be wondered at. I do not think, however, that the subsidence of the surface usually takes place so suddenly. As a rule it will be in the ratio of the dissolution of the underlying rock-salt beds. It has frequently struck me that some of the small "Meres" in Cheshire have originated under similar circumstances. In Norfolk we frequently have subsidences of the surface by the dissolution of chalk by sand-pipes. In many parts of Lancashire and Staffordshire the surface of the country sinks where mining operations are carried on. This is best told by the great depth of the neighbouring canals, whose banks have had to be built up in order to preserve the level of the water. Near Dukinfield, the canal is in many places over twelve feet deep-the depth being a good index to the amount of subsidence undergone in consequence of the coal having been worked underneath. Newspaper paragraphs relating the sudden sinking of small areas are not rare in Norfolk, the usual vulgar explanation of them being of course earthquake action. Rock salt is much more readily soluble than Chalk, so that it is very probable the subsidences in Cheshire and Norfolk are due to the similar action of water in dissolving and removing the solid matter of the strata beneath. J. E. TAYLOR.

NoRwicr, June 13, 1869.

\section{MISCFIIAINEOUS.}

A Gigantio Oolimio Lizard.--Prof. Phillips has lately recorded the discovery - in a quarry at Enslow Bridge, a few miles north of Oxford-of the femur of a monstrous lizard of the Oolitic age, measuring five feet and a third (sixty-four inches) in length, and 44.25 inches round the distal extremity; while the breadth at the upper end (taken obliquely) is $20 \cdot 75$ inches, and the circumference 46.0 inches. A similar bone (but not nearly so large) in the Oxford Museum was referred by the late Hugh E. Strickland to Prof. Owen's genus Cetiosaurus, to which genius no doubt this gigantic femoral belonged. 